\title{
Unspooling the Legacy of Submarine Cables
}

\author{
M. Wynn Tranfield
}

Submarine cables represent an invisible yet crucial infrastructure that enable all manner of global communication. Despite their impact, they are seldom a matter of public interest or debate. Further, they are uniquely represented in state, federal, and international legislation. Throughout history, legislative concerns surrounding submarine cables have shifted from colonial monopolies to environmental health and national security. The following document examines the evolution of submarine cables from the first transatlantic copper wire cable to the present fiber-optic cable boom through the legislative lens.

O ver 95 percent of all international communications are routed through submarine cables, which are an almost invisible infrastructure upon which global trade depends. ${ }^{1}$ There are more than a million kilometers of cables linking every continent except Antarctica like threads in a web. The first cable crossing relied on a single copper wire insulated with guttapercha, a latex derivative, and has since evolved into fiber optics that can accommodate streaming video in the blink of an eye. ${ }^{2}$ Submarine cables have also been uniquely protected and promoted by international treaties since 1884 . They are a resource that has fueled globalization, enabling rapid communication over long distances.

In 1866, the first transatlantic cable opened the doors for telegraphic globalization and long-term social changes (see figure 1). At first, telegram prices were so high that functional use was limited to government, business, or otherwise elite patrons. ${ }^{3}$ British colonial powers were primary drivers, incentivized by both improved communication with colonies and monopolized access to raw materials, namely rubber. The rubber was necessary for cable insulation. Thus, as cable routes expanded they followed the trade routes of British colonial powers. Increasing globalization cemented the need for reliable communication. As fiber optics and the World Wide Web have expanded, demand for cable use routes have grown and diversified. We are in the midst of a "cable boom," as countries and telecommunication companies rush to supply bandwidth to users. Large software companies like Facebook and Microsoft are also taking the plunge, investing in their own proprietary submarine cables. Demand for international bandwidth doubled from 2014 to 2016 and is steadily increasing. ${ }^{4}$

The geographies of cable landing sites can be complex and have an impact on the surrounding environment. Their installation and maintenance alone can cause serious habitat disruptions, particularly to benthic species or larger mammals that traverse oceanic zones. During the 1950s, it was not uncommon for whales to get tangled in lightweight telegraph cables. ${ }^{5}$ Presently, modern cables are engineered to be heavy enough to rest on the seafloor without tangling but remain approximately the width of a garden hose (see figure 2). The United Nations Environment Programme (UNEP) and the International Cable Protection Committee (ICPC) have laid out international directives for cable-laying and suggested treatments. However, many of the more fragile coastline habitats fall within territorial waters. In the United States, there is a rich history of legislation and reports detailing submarine cables from their infancy until around 1920. Following that, there was a long silence until the 1990s when our understandings of environmental protection called for stronger legislation in that arena. Permitting is an ongoing concern which has been passed through the hands of several federal bodies and requires the input of many disparate departments. The following document examines the history of submarine cables through the lens of United States legislation, from British domination to our present privatized boom.

\section{Regulations-Historic}

The first mention of submarine cables in United States government legislation arose in 1884 when President Grover Cleveland issued a proclamation acknowledging a legal precedent for reimbursed repair work following negligent or willful 


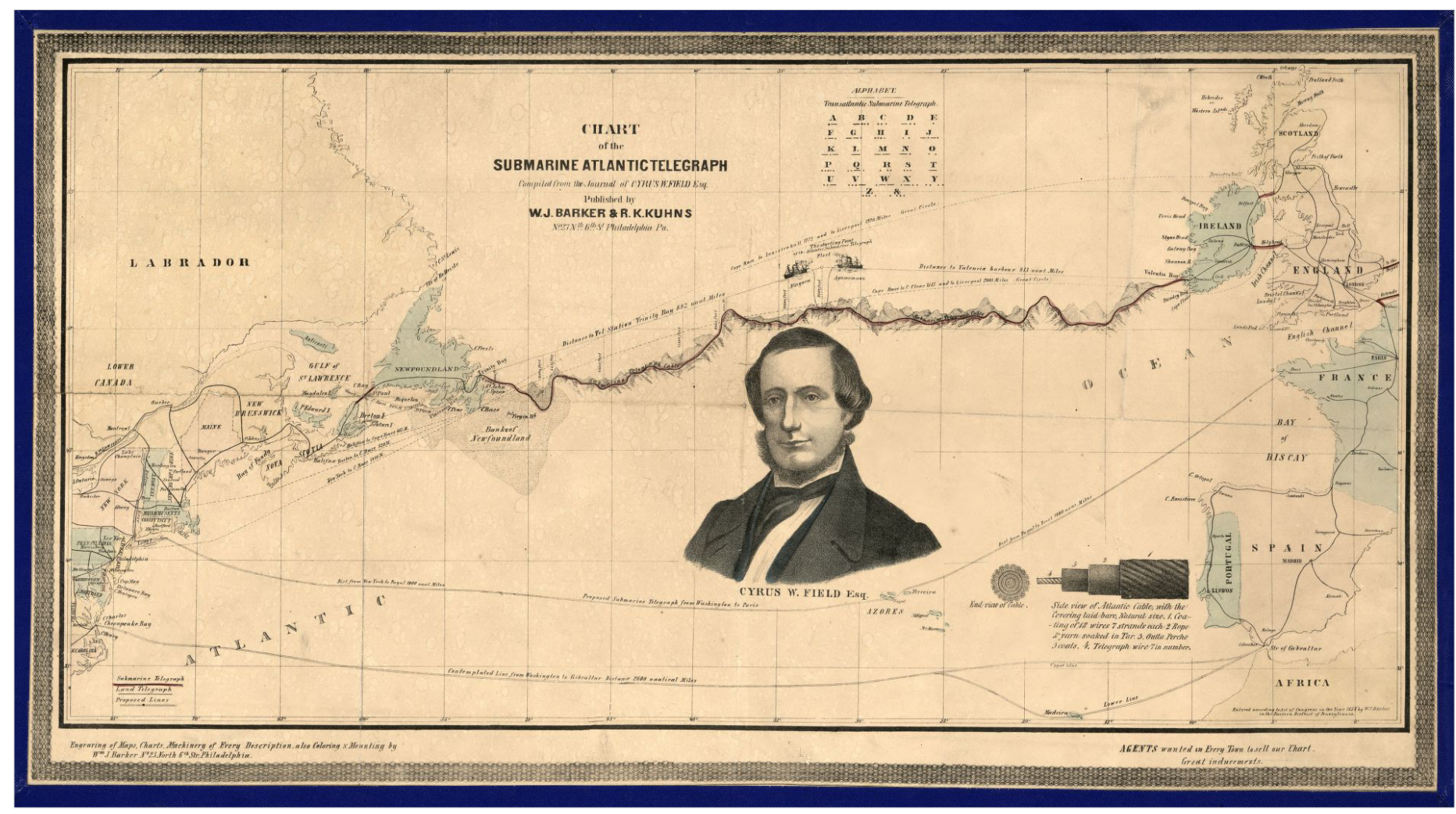

Figure 1. Chart of the much-hailed Atlantic Telegraph Wire linking Ireland and Newfoundland. William J. Barker, Chart of the Submarine Atlantic Telegraph (Philadelphia:W.J. Barker \& R.K. Kuhns, 1858), map, retrieved from the Library of Congress, https://www.loc.gov/item/2013593216/.

disruption of a cable. ${ }^{6}$ The Submarine Cables Act of 1886 states that any person who attempts or succeeds at injuring a submarine cable so as to "interrupt or embarrass" the telegraphic communication is guilty of a misdemeanor offense and liable to a fine or imprisonment. ${ }^{7}$ Negligent injury, such as that caused by an errant fishing net, is considered a misdemeanor. A treaty was ratified in 1886 and eventually recognized by the majority of coastal governments involved in global trade, including France, Brazil, and Japan. ${ }^{8}$ This treaty has been updated to reflect advances in cable technology and inflation, but the intentions of the legislation remain identical. ${ }^{9}$

President Cleveland saw the importance of maintaining close relations with British-controlled telegraph companies (see figure 3). In the Atlantic, a price war ensued between the three main players (Telcon, the Anglo-American Telegraph Co., and Western Union Telegraph Co.) to see who could provide the lowest rates. Each company underbid the next, nearly to the detriment of the entire industry. ${ }^{10}$ The Sherman AntiTrust Act of 1890 addressed price-fixing, but Cleveland saw the need for more control over future cable endeavors. ${ }^{11} \mathrm{He}$ established a precedent that citizens of the United States should "stand on the same footing" as citizens of other terminus countries with regard to priority and cost of message. ${ }^{12}$ Since cable communication was swiftly becoming a necessity, it would be a catastrophic mistake for the American people to become subject to the whims of an industrial baron.

The turn of the century saw a push for more cable development beyond the Atlantic theatre into the Pacific. In a statement to the Committee on Interstate and Foreign Commerce, J. A. Scrymser, president of the Pacific Cable Company, asked for the contract to what would eventually become the first Pacific cable. The cable was slated to connect the West Coast to the Hawaiian Islands, then on to China and Australia. ${ }^{13}$ At the time, 120,000 of the 160,000 miles of submarine cables in operation were owned by Great Britain or British subsidiaries. Only 22,000 miles were under US control. ${ }^{14}$ The cable was eventually completed by the Pacific Cable Company; however, further legislative hearings reflect a long tail of claims against the US Navy by the Pacific Cable Co. for damaging the cable at landing sites around Hawaii and other Pacific islands. ${ }^{15}$

In 1917 President Woodrow Wilson issued an executive order addressing the state of war between the United States and Germany. Wilson decried that all companies or persons owning, controlling, or operating telecommunication-related submarine cables are prohibited from transmitting messages to points outside the continental United States or "on or near" the 


\section{Tranfield}

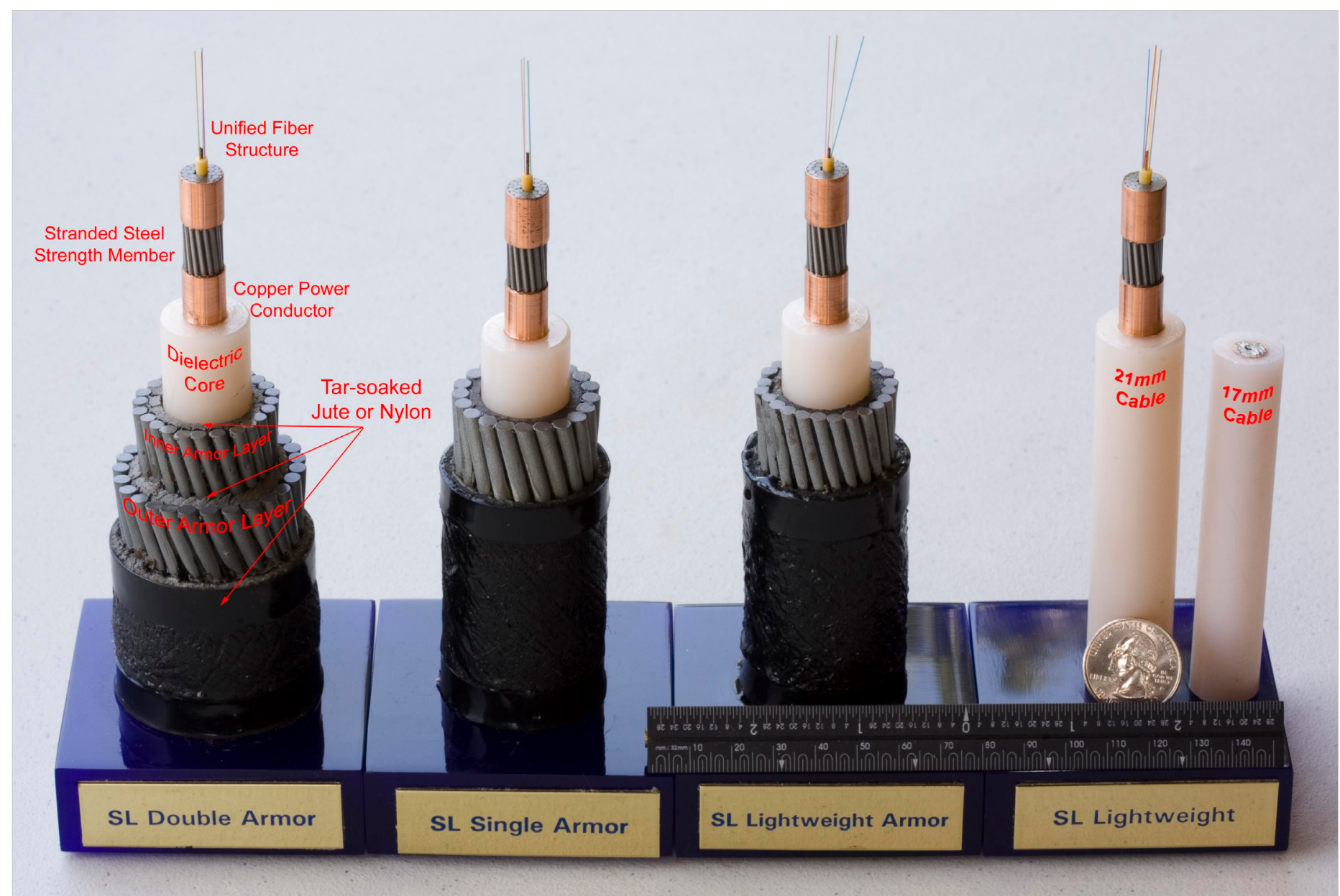

Figure 2. Modern fiber-optic cables. The light-weight (right) cables are typically used in the deep ocean. Armored cables (left) are used on coastlines. Lonnie Hagadorn, Submarine Optical Cables, 2009, Wikimedia Commons. Creative Commons Attribution-ShareAlike 4.0 International. https://commons .wikimedia.org/wiki/File:Submarine_Optical_Cables.jpg.

Mexican border. ${ }^{16}$ This was also the first indication that cables could be used as an espionage tool. The Secretary of War and Secretary of the Navy were given exemptions, and able to operate the cable at their own discretion. The United State government established the full authority to control cable landings in 1921 through the Kellogg Act. ${ }^{17}$ The Kellogg Act resulted in at least one instance of a naval intervention to block the unlawful landing of a Western Union Telegraph Co. cable linking Barbados to Miami Beach. ${ }^{18}$ Perhaps sensing the need for more oversight, President Warren G. Harding issued an order in 1921, directing permissions for all new cable landings to go through the Secretary of State. ${ }^{19}$ This was amended in 1934 to transfer permissions to the newly created Federal Communications Commission (FCC) ${ }^{20}$ Further authorization for the FCC to address permits was provided by Executive Order 10530 in $1954 .^{21}$

\section{The Present}

There was little attention paid to submarine cables from the 1960 s into the 1990s, largely because of static technological development. What changed was the number of influencing regulatory agencies with vested coastline interests. The formation of the National Oceanic and Atmospheric Administration (NOAA) was compelled by the Marine Resources and Engineering Development Act of $1966,{ }^{22}$ when a number of agencies associated with the marine wildlife, safety, and resource development joined under one umbrella. Upon its formation, President Richard Nixon elected to nest it within the Department of Commerce instead of the Department of the Interior, allegedly as payback to the head of the Department of Interior for his comments about the Vietnam War. ${ }^{23}$ President Obama joked that this was why we had one agency that monitored salmon in fresh water and a completely different one that monitored salmon in salt water. ${ }^{24}$ NOAA is essentially an environmental agency, although it is nested within an agency whose express purpose is to help the American economy grow. 


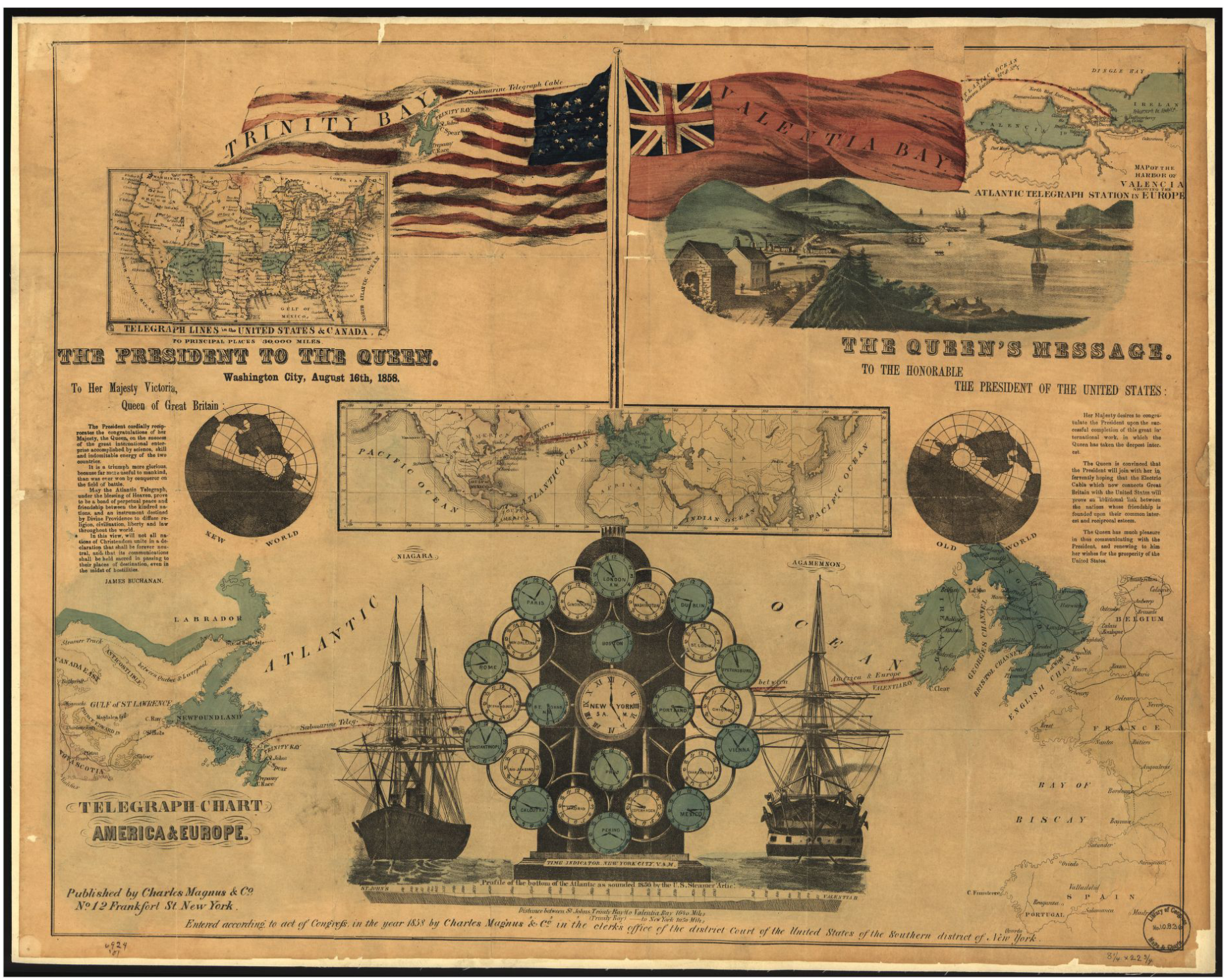

Figure 3. In the early years of the Transatlantic cable, both sides of the ocean were thrilled with the prosperity promised by expedient communication. Charles Magnus \& Co., Telegraph Chart, America and Europe [S.I, 1858], map, retrieved from the Library of Congress, https://www.loc.gov/item/99466769/.

The NOAA oversees the National Marine Sanctuaries Act of 1972 (NMSA), forcing the Secretary of Commerce to designate and protect "significant" marine areas. ${ }^{25}$ Within those areas, approvals and regulations for submarine cable-laying are delegated to NOAA before they can be approved by the FCC. Currently, there are fourteen designated marine sanctuaries subject to NMSA Special Use permissions and monitoring. If a submarine cable laying permit is requested, NMSA authorizes NOAA to conduct Environmental Impact Assessments and issue discretionary permits for the "placement and recovery of objects associated with public or private events on non-living substrate of the submerged lands of any national marine sanctuary" and "the continued presence of commercial submarine cables on or within the submerged lands of any national marine sanctuary." ${ }^{26}$ NOAA may also request a "fair market value" fee for continued monitoring and administrative fees associated with marine sanctuary monitoring. ${ }^{27}$

Also listed under the NOAA umbrella are requirements to adhere to regulations outlined in the Endangered Species Act and Marine Mammal Protection Act. The Endangered Species Act prevents the "taking" of an endangered species, broadly defined as the harassment, pursuit, hunting, shooting, wounding, killing, trapping, capturing, or collecting of specimens. ${ }^{28}$ The Marine Mammal Protection Act takes this a step farther by protecting marine mammals from externalities such as elevated noise levels and increased traffic. Cables can participate in the "taking" of endangered species or mammals by increasing noise and traffic during installation, disturbing sediments, and tying up kelp. ${ }^{29}$ 
Overlapping all permitting and exceptions is the Antiquities Act, which allows the President of the United States to declare federal lands as national monuments. ${ }^{30}$ The land must have some significant natural, cultural, or scientific value in order to qualify. ${ }^{31}$ In fact, the largest such monument is the Papahānaumokuākea Marine National Monument surrounding the Hawaiian Archipelago, established June 2006. ${ }^{32}$ Papahānaumokuākea Marine National Monument is automatically considered a Marine Sanctuary, subject to additional environmental protections.

The first transatlantic fiber-optic cable laid in 1988 pioneered what would become an eventual 1.25 million kilometers of

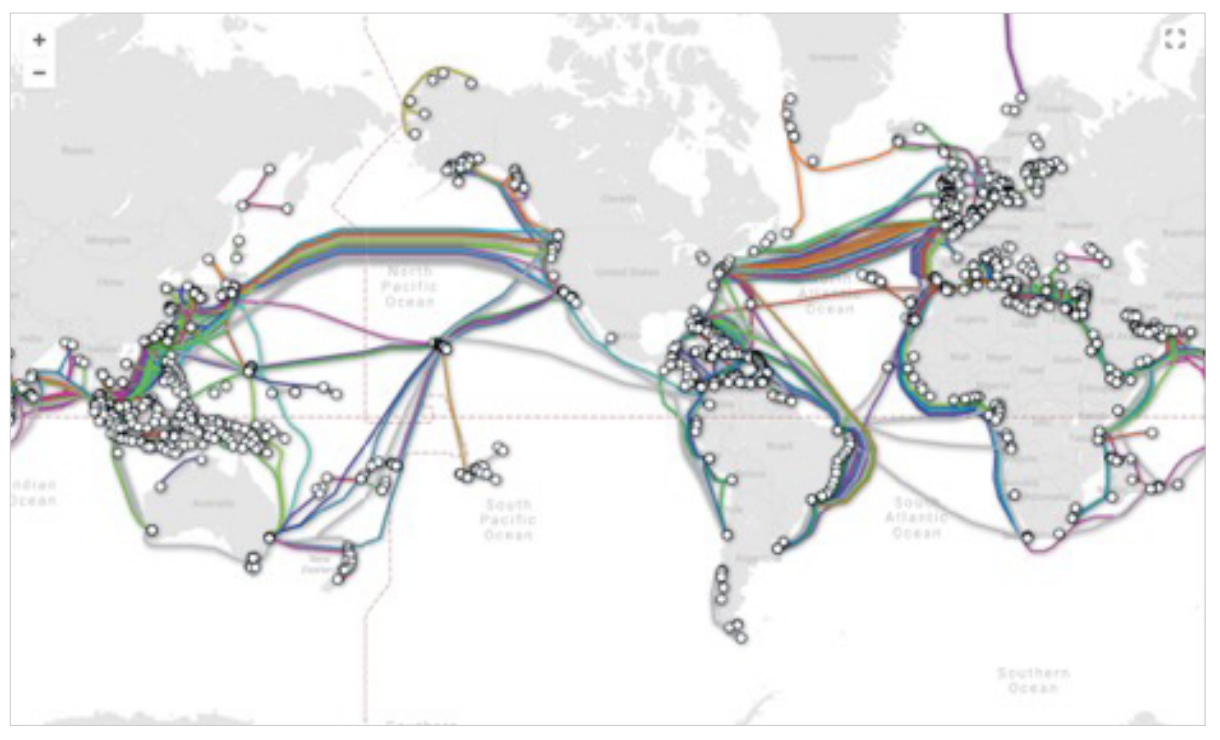

Figure 4. Current snapshot of the Global Submarine Cable Landscape. TeleGeography, Submarine Cables, March 2018, TeleGeography. Creative Commons Attribution-NonCommercial-NoDerivs 3.0 Unported License, https://www.submarinecablemap.com. fiber-optic cables added over the next twenty-five years to support the modern internet. ${ }^{33}$ This development renewed political and environmental interest at a global level. The document governing the majority of Earth's surface is provided by the United Nations Convention of the Law of the Sea (UNCLOS), which came into effect in $1994 .{ }^{34}$ Broadly, the Convention outlines the rights and responsibilities of nations sharing use of the ocean as a resource and defines International Maritime Boundaries. The Convention recognized existing agreements governing submarine cables, ${ }^{35}$ submarine cables on the continental shelf, ${ }^{36}$ and the rights of a country or corporation to lay submarine cables and receive compensation for losses. ${ }^{37}$ This means an archipelagic state or group of states, such as the Antilles in the Caribbean Sea, must respect the existing cables that traverse their waters without making landfall, and permit maintenance and replacement of the cable as the owner sees fit. Fundamentally, UNCLOS reinforces the "Freedom of the High Seas," permitting any nation, coastal or landlocked, to lay submarine cables in International waters. ${ }^{38}$

Although the United States remains the only maritime power to have not officially ratified UNCLOS due to disagreements over deep-sea mining constraints, ${ }^{39}$ they otherwise practice de-facto compliance. Details of the cable landing requirements are outlined in greater detail by the FCC, who acknowledge that there are many additional application and certification requirements depending on the nationality of the applicant and state of proposed landing. ${ }^{40}$ For example, in the United States a number of states have chosen to exercise their rights under the Submerged Lands Act of 1953, extending state's rights three nautical miles from shore. ${ }^{41}$ Overlapping the Submerged Lands Act of 1953 is the Coastal Zone Management
Act of 1972, which allows states the authority to review federal activities affecting land or water use. ${ }^{42}$ Environmental Impact Assessments are expected. Due to these overlapping jurisdictions, the FCC suggests that applicants be vigilant and submit applications at least six months in advance. ${ }^{43}$

\section{The Future}

For a company to receive permission to land a telecommunications cable with a non-continental terminus on the shore of the United States, the company must complete a great deal of paperwork. First, they must receive permits from the coastal state in question, clear NOAA requirements, and finally receive permission from the Federal Communications Commission. It is not an easy process, but it is a relatively private process and one that does not call for public input. ${ }^{44}$ Once the cable is laid, their notation on nautical charts is wholly at the discretion of NOAA. ${ }^{45}$ Despite how vital cables are, there is very little public discussion about regulations and physical presence. There may never be a public mention of a tangible connection between continents. It is ironic that cable infrastructure is so poorly communicated about, yet so necessary for global communication (see figure 4).

This may be changing as lawmakers become increasingly aware of national security concerns associated with cable facilities. Recently, the FCC passed a ruling requiring submarine cable licensees to formally report outages, or "a failure or significant degradation in the performance of a licensee's cable service regardless of whether the traffic can be re-routed to an alternate path." ${ }^{16}$ This data was previously collected on an ad-hoc basis, leaving questions about infrastructure vulnerabilities. This may 
also be due to increasing security concerns. A recent US Army War College Strategy Research Report addresses the dependence of international voice and data traffic on the well-being of the cables. The greatest threats to cables appear to come from mariners who inadvertently drag nets along the ocean floor. ${ }^{47}$

\section{Conclusion}

The value of the submarine cable to modern life cannot be understated, yet we are only beginning to see this supported in legislation and the public record. There has been a massive amount of time, energy, capital, and labor invested in maintaining these cable networks and their infrastructures. ${ }^{48}$ They are the literal threads that bind the globe, and rare examples of successful international treaty-making. The early transatlantic years are a thoughtful look back into a world yet to be globalized, startled by a technology that could transmit a message faster than a swift horse. Early messages were priced by the word, too expensive for the layperson. Yet a mere century later, we can easily exchange live video feeds around the world. While past legislation regulated monopolies, landing permissions, and damages, today's legislation attempts to balance long-term geopolitical and environmental interests while supporting economic and technological development. It will be interesting to revisit this topic in the future to determine the impact of cybersecurity concerns on legislative decisions.

\section{References}

1. Lionel Carter et al., Submarine Cables and the OceansConnecting the World, UNEP-WCMC Biodiversity Series no. 31 (ICPC/UNEP/UNEP-WCMC, 2009), http:// www.iscpc.org/publications/icpc-unep_report.pdf.

2. Douglas R. Burnett, Robert C. Beckman, and Tara M. Davenport, Submarine Cables: The Handbook of Law and Policy (Leiden: BRILL, 2013).

3. Henniker Heaton quoted in Simone M. Müller, "Beyond the Means of 99 Percent of the Population: Business Interests, State Intervention, and Submarine Telegraphy," Journal of Policy History 27, no. 3 (2015): 446; see also Richard R. John, "Letters, Telegrams, News," Edinburgh Companion to Nineteenth-Century American Letters and Letter-Writing, ed. Celeste-Marie Bernier, Judie Newman, and Matthew Pethers, 119-30 (Edinburgh, Scotland: Edinburgh University Press, 2016).

4. Jim Poole, "Submarine Cable Boom Fueled by New Tech, Soaring Demand," Network World, March 6, 2018, https://www.networkworld.com/article/3260784 /lan-wan/submarine-cable-boom-fueled-by-new-tech -soaring-demand.html.

5. Carter etal.,Submarine Cablesand the Oceans-Connecting the World, 9.

6. Protection of Submarine Cables, Declaration and final protocol between the United States of American and other powers ratifying the International Convention of March 14, 1884, for the protection of submarine cables, December 1, 1886, 25 Stat. 1424, https://con gressional.proquest.com/congressional/docview/t53 .d54.00025-stat-1424-000001 accountid $=130717$.

7. Submarine Cables, 47 U.S.C. 22 (1997), \$\$ et seq.

8. Protection of Submarine Cables, March 14, 1884. 24 Stat. 989.

9. Protection of Submarine Cables, (1886) 25 Stat. 1424.

10. Burnett, Beckman, and Davenport, Submarine Cables, 26-27.

11. An Act to Protect Trade and Commerce Against Unlawful Restraints and MNonopolies, (1890), 26 Stat. 209, http:// legisworks.org/sal/26/stats/STATUTE-26-Pg209a.pdf.

12. US President, A Final Protocol between the United State and Other Powers, for the Protection of Submarine Cables, signed at Paris, July 7, 1887. December 14, 1887, 50th Cong., 1st sess., 1887, S. Doc. No. 79-122, at 16-17.

13. House Committee on Interstate and Foreign Commerce, The Pacific Cable Bills: Hearing on H.R. 5989 and H.R. 5499, 55th Cong., 2nd sess. (1898) (statement of James A. Scrymser, President of Pacific Cable Company).

14. Ibid.

15. Senate Committee on Claims, To Pay Commercial Pacific Cable Company, 64th Cong., 1st sess. 1916, S. Rep. 371; House Committee on Claims, Findings of Court of Claims in Case of Commercial Pacific Cable Co., 64th Cong., 2d sess., 1917, H. Rep. 1450; An Act For the relief of the Commercial Pacific Cable Company, 43 Stat. 1373.

16. Exec. Order No. 2604 (1917), Censorship of Submarine Cables, Telegraph and Telephone Lines.

17. An Act Relating to the Landing and Operation of Submarine Cables in the United States, (1921) 42 Stat. 8.

18. A Bill to Prevent the Unauthorized Landing of Submarine Cables in the United States: Hearings before a Subcommittee of the Committee on Interstate Commerce on S. 4301. 66th Cong., 2nd sess., (1920), at 6-7.

19. Exec. Order No. 3513, (1921).

20. Exec. Order No. 6779, (1934), Amendment of E.O. 3513 of July 9, 1921, Relating to Applications for Submarine Cable Licenses. 
21. Exec. Order No. 10530 (1954), Providing for the Performance of Certain Functions Vested in or Subject to the Approval of the President.

22. Marine Resources and Engineering Development Act of 1966, (1966) 80 Stat. 203.

23. Barack Obama, "Remarks on Government Reform, January 13, 2012," in Compellation of Presidential Documents, Office of the Federal Register, National Archives and Records Administration (Washington, DC: GPO 2012), 1, https://www.govinfo.gov/content/pkg/DCPD -201200020/pdf/DCPD-201200020.pdf.

24. Ibid.

25. National Marine Sanctuaries Act, 16 U.S.C. 1431-1445 (2000), https://nmssanctuaries.blob.core.windows.net/san ctuaries-prod/media/archive/library/national/nmsa.pdf.

26. Department of Commerce, "Final Notice of Applicability of Special Use Permit Requirements to Certain Categories of Activities Conducted Within the National Marine Sanctuary System, 2013, Notice," 78 Federal Register 25957 (May 3, 2013), https://nmssanctuaries .blob.core.windows.net/sanctuaries-prod/media/archive /management/fr/78fr25957.pdf.

27. National Marine Sanctuaries Act, 16 U.S.C. 1441 (2000), https://nmssanctuaries.blob.core.windows.net/sanctuaries -prod/media/archive/library/national/nmsa.pdf.

28. Endangered Species Act of 1973, 87 Stat. 884, https:// www.gpo.gov/fdsys/pkg/STATUTE-87/pdf/STAT UTE-87-Pg884.pdf.

29. Marine Mammal Protection Act, 86 Stat. 1027, https:// www.gpo.gov/fdsys/pkg/STATUTE-86/pdf/STAT UTE-86-Pg1027.pdf.

30. Irina Kogan, et al., Environmental Impact of the ATOC/ Pioneer Seamount Submarine Cable. Monterey Bay National Marine Sanctuary (November 2003), https://nmsmon tereybay.blob.core.windows.net/montereybay-prod /media/research/techreports/cablesurveynov2003.pdf.

31. Antiquities Act, 34 Stat. 225, https://www.nps.gov/history /local-law/FHPL_AntiAct.pdf.

32. Ibid.

33. George W. Bush, Proclamation 8031, "Establishment of the Northwestern Hawaiian Islands Marine National Monument," 71 Federal Register 36443 (June 26, 2006), https://nmspapahanaumokuakea.blob.core.windows .net/papahanaumokuakea-prod/media/archive/pdf /proclamation_8031.pdf.
34. UN General Assembly, "Chapter 19: Submarine Cables and Pipelines," The First Global Integrated Marine Assessment, World Ocean Assessment I (January 21, 2016), http://www.un.org/depts/los/global_reporting/WOA_ RegProcess.htm.

35. UN General Assembly, Convention on the Law of the Sea, (December 10, 1982), http://www.un.org/depts/los/con vention_agreements/texts/unclos/unclos_e.pdf.

36. Ibid., Article 51.

37. Ibid., Article 79.

38. Ibid., Articles 112-15.

39. Ibid., Article 87.

40. Ronald Reagan, "Statement on United States Oceans Policy," March 10, 1983, online by Gerhard Peters and John T. Woolley, The American Presidency Project, http:// www.presidency.ucsb.edu/ws/?pid= 41036 .

41. Cable Landing Licenses, 47 C.F.R. $\$ 1.767$ (2017): 206-12, https://www.gpo.gov/fdsys/pkg/CFR-2017-title47-vol1 /pdf/CFR-2017-title47-vol1-sec1-767.pdf.

42. An Act to Confirm and Establish the Titles of the States to Lands Beneath Navigable Waters within State Boundaries and to the Natural Resources within Such Lands and Waters, and to Provide for the Use and Control of Said Lands and Resources and the Resources of May 22, 1953, 67 Stat. 29.

43. Coastal Zone Management Act, 86 Stat. 1280, https:// www.gpo.gov/fdsys/pkg/STATUTE-86/pdf/STAT UTE-86-Pg1280.pdf.

44. FederalCommunications Commission, "SubmarineCable Landing Licenses," https://www.fcc.gov/research-reports /guides/submarine-cable-landing-licenses.

45. Representation of Submarine Cables and Pipelines on Nautical Charts. 33 C.F.R. 209.310 (2001), https:// www.gpo.gov/fdsys/granule/CFR-2001-title33-vol3 /CFR-2001-title33-vol3-sec209-310.

46. Federal Communications Commission, "Improving Outage Reporting for Submarine Cables and Enhanced Submarine Outage Data," 81 Federal Register 5235452363 (August 8, 2016), https://www.gpo.gov/fdsys/pkg /FR-2016-08-08/pdf/2016-18610.pdf.

47. Michael S. Matis, "The Protection of Undersea Cables: A Global Security Threat," U.S. Army War College (July 2012): 24, http://www.dtic.mil/dtic/tr/fulltext/u2/a561426 .pdf.

48. Nicole Starosielski, The Undersea Network (Durham: Duke University Press, 2005), 13. 